Trinity University

Digital Commons@ Trinity

History Faculty Research

History Department

$9-2015$

\title{
To Support a "Brother in Christ": Evangelical Groups and U.S.-Guatemalan Relations During the Ríos Montt Regime
}

Lauren Frances Turek

TrinityUniversity, lturek@trinity.edu

Follow this and additional works at: https://digitalcommons.trinity.edu/hist_faculty

Part of the History Commons

\section{Repository Citation}

Turek, L.F. (2015). To support a "Brother in Christ": Evangelical groups and U.S.-Guatemalan relations during the Ríos Montt regime. Diplomatic History, 39(4), 689-719. doi: 10.1093/dh/dhu039

This Post-Print is brought to you for free and open access by the History Department at Digital Commons @ Trinity. It has been accepted for inclusion in History Faculty Research by an authorized administrator of Digital Commons @ Trinity. For more information, please contact jcostanz@trinity.edu. 
To Support a "Brother in Christ":

Evangelical Groups and U.S.-Guatemalan Relations during the Ríos Montt Regime ${ }^{1}$

On March 23, 1982, a group of young officers in the Guatemalan army staged a coup d'état at the National Palace in Guatemala City. After ordering the president, General Romeo Lucas García, to step down, the young officers announced their intention to replace him with a temporary military junta that would rule until Guatemala could hold free elections for a new president. ${ }^{2}$ The officers named Brigadier General José Efraín Ríos Montt, General Horacio Maldonado Schaad, and Colonel Luis Gordillo Martínez as the leaders of the junta. ${ }^{3}$ Not on active duty at the time of the coup, Ríos Montt learned of the decision from a radio broadcast calling him to the National Palace while he prepared for student-teacher meetings in his role as academic director at el Verbo ("The Church of the Word") Christian day school. ${ }^{4}$ Prior to accepting the army's call, Ríos Montt asked for guidance from the elders of el Verbo, a neoPentecostal church that missionaries from the Eureka, California-based Gospel Outreach Church had founded in 1976 and continued to direct.

In an interview four days after the coup, U.S. missionary and el Verbo governing church elder Carlos Ramírez told reporters that following the young officers' call, he and the other

\footnotetext{
${ }^{1}$ This essay began as a paper for the 2013 SHAFR conference. It benefited from comments from panel members Seth Jacobs, Andrew Preston, Melani McAlister, and Benjamin Brandenburg. I would also like to thank Melvyn Leffler, James Wilson, Stephen Macekura, Rhonda Barlow, Mary Barton, Evan McCormick, and the two anonymous readers for Diplomatic History for their invaluable feedback.

${ }^{2}$ Frederic Chapin, United States Embassy, Guatemala to United States Department of State, Washington, "Coup Sitrep No. 5," March 23, 1982, Confidential Cable 002106, Digital National Security Archive (hereafter DNSA), nsarchive.chadwyck.com (accessed 14 November 2011); Frederic Chapin, United States Embassy, Guatemala to United States Department of State, Washington, “Coup Sitrep No. 13,” March 24, 1982, Confidential Cable 002115, DNSA, 2.

${ }^{3}$ Chapin, "Coup Sitrep No. 13," 2.

${ }^{4}$ Joseph Anfuso and David Sczepanski, He Gives-He Takes Away: The True Story of Guatemala's Controversial Former President Efrain Rios Montt (Eureka, CA: Radiance Publications, 1983): 111. Global Outreach church, which established el Verbo in Guatemala in 1976, published this account shortly after a coup removed Ríos Montt from power in August, 1983. Curriculum Vitae del Gral. Rios Montt (25 March 1982), in Civil War, Society and Political Transition in Guatemala: The Guatemala News and Information Bureau Archive, 1963 - 2000 (Woodbridge, CT: Primary Source Microfilm, 2004): Series 5, Roll 13.
} 
elders had gathered "to lay hands on Efraín, to pray over him as the Bible teaches, and basically send him out from us with His blessings to the palace." ${ }^{5}$ Through prayer with these church leaders, Ríos Montt came to believe that God had ordained him to lead the junta. ${ }^{6}$ Within a few months, he had marginalized the two other junta members, and he declared himself president of Guatemala on June $5,1982 .{ }^{7}$ In public speeches and weekly radio and television sermonettes, Ríos Montt emphasized his certainty that "the Lord God, in his infinite wisdom, had given [him] the command to save the people of Guatemala," a belief the elders of el Verbo nurtured. ${ }^{8}$ As president, he pledged to bring Christian moral precepts to bear on the problems of the nation, and he called on the people and God to help him create a new Guatemala. ${ }^{9}$

\section{[FIGURE 1]}

Ríos Montt's rhetoric and the evident sincerity of his beliefs captured the imagination of internationalist evangelical Christians in the United States. Seeing great potential to spread the gospel in Central America through Ríos Montt's Christian leadership, American evangelicals and parachurch organizations aided his regime directly through public outreach, fundraising, and congressional lobbying. Despite mounting evidence that his campaign against Guatemala's "communist insurgency" involved the mass killing of indigenous Mayans, evangelical groups argued that the dictator's Christian faith would compel him to improve the country's human

\footnotetext{
${ }^{5}$ Carlos Ramírez, interview by Bonnie Anderson and John Hart, "Headline: Guatemala / Rios Montt," NBC Evening News, 27 March 1982, available from: http://tvnews.vanderbilt.edu/program.pl?ID=522679.

${ }^{6}$ Anderson and Hart, "Headline: Guatemala / Rios Montt"; Anfuso and Sczepanski, He Gives, 114-115, 117; Frederic Chapin, United States Embassy, Guatemala to United States Department of State, Washington, "Piedra/Carbaugh Visit: Impressions of President Rios Montt," May 19, 1982, Confidential Cable 003591, DNSA.

${ }^{7}$ Paul Taylor, United States Embassy, Guatemala to United States Department of State, Washington, "The Rios Montt Presidency: A First Assessment," June 16, 1982, Confidential Cable 004301, DNSA.

${ }^{8}$ Adolfo Aguilar Zinser, "De La Tierra Arrasada a La Aldea Estrategica," Crie Documentos Guatemala 4 (Septiembre, 1982), Archivo de la Coordinadora Alemana de Solidaridad con Guatemala, Cartapacio No. 156 Coleccion Infostelle Del 13.01.06 Al 13.01.07, Centro de Investigaciones Regionales de Mesoamérica, Antigua Guatemala, Sacatepéquez, Guatemala (hereafter CIRMA).

9 “Así lo dijo anoche en su mensaje por televisión el general Ríos Montt," Prensa Libre (27 December 1982), Publicación Diario El Imparcial, Serie: La Morgue (recortes de periódicos), Presidente: Gral. Rios Montt (19821983) Ramo: Gob, CIRMA.
} 
rights situation. Neo-Pentecostal missionaries and their Guatemalan brethren played a key role in the Ríos Montt regime, shaping the dictator's discussions with the Reagan administration, factoring into his internal strategic planning, and guiding his understanding of his role as a Christian leader. Support from U.S. and Guatemalan evangelicals for Ríos Montt and for Reagan administration efforts to extend military aid to Guatemala became significant factors shaping relations between the two countries.

The intricate, overlapping web of influence that U.S. Christians wove—or found themselves woven into-in Guatemala in the early 1980s exemplified the transnational connectivity, shared evangelistic goals, and extensive reach of the global evangelical community. This essay links the circumstances and socio-political implications of the proliferation of Pentecostal and neo-Pentecostal churches in Guatemala during the late 1970s with the theological and political beliefs that underpinned evangelical support for Ríos Montt in the United States in the 1980s. It argues that connections between evangelicals in the United States and in Guatemala influenced U.S. relations with the Ríos Montt regime and the response of the Guatemalan government to U.S. policies. It offers a unique contribution to our understanding of the political implications of global evangelicalism, placing evangelical involvement in the Ríos Montt regime in an international context as part of a larger crusade to evangelize the world, and also reveals how non-state actors shaped U.S. relations with Central America in this period. ${ }^{10}$

\footnotetext{
${ }^{10}$ Scholars of religion, sociology, political science, and history have examined this period in Guatemalan history from various perspectives. Those that explore evangelicalism and the Ríos Montt regime focus on how this dynamic played out in Guatemala exclusively, though some discuss the role of American evangelicals within Guatemala and their ties with the Reagan administration. This paper builds on works that expose the involvement of American evangelicals in supporting the Ríos Montt regime, but shifts the focus to examine this phenomenon from the perspective of U.S. international relations and foreign policy making. In viewing these events through the lens of recent scholarship on non-governmental organizations and internationalist Christian outreach, it links the evangelistic aims of U.S. Christians with geopolitical developments abroad, offering new insight into how evangelicals affected US-Central American relations. For the definitive book on Ríos Montt's presidency, counterinsurgency campaigns, and genocide against the Maya, see Virginia Garrard-Burnett, Terror in the Land of the Holy Spirit: Guatemala under General Efrain Ríos Montt, 1982 - 1983 (Oxford: Oxford University Press,
} 


\section{From Jesus Freaks to Global Outreach: Sending Spiritual Aid to the Suffering}

At just after 3am on the morning of February 4, 1976, a devastating $7.5 \mathrm{Mw}$ earthquake struck Guatemala, radiating death and destruction throughout the country. 23,000 people perished and more than 76,000 suffered injuries. ${ }^{11}$ The earthquake exacted a staggering economic toll, leaving over a million homeless, with large swaths of Guatemala City and other towns reduced to rubble and critical infrastructure destroyed. ${ }^{12}$ Christian relief agencies and churches in the United States responded immediately, sending food, clothing, building supplies, and medical aid to help in the rescue and recovery efforts. The response from these groups proved so effective that within two weeks of the earthquake, the Ford administration's coordinator for disaster relief "urged persons wishing to help to contact church and private sector organizations," rather than government agencies. ${ }^{13}$ Although most Guatemalans were at least nominally Catholic at the time, evangelical Christian groups, including the National Association of Evangelicals' World Relief Commission, the Assemblies of God World Missions, and the Southern Baptist Foreign Mission Board, delivered substantial aid to their brethren and others suffering from the effects of the earthquake. ${ }^{14}$ They also sent in missionaries. Ultimately, the extent and success of the evangelistic outreach that the earthquake triggered turned Guatemala

2010). On the role of evangelicalism in the Guatemalan Civil War and Ríos Montt's counterinsurgency strategy, see Veronica Melander, The Hour of God?: People in Guatemala Confronting Political Evangelicalism and Counterinsurgency (1976-1990) (Uppsala: Swedish Institute of Missionary Research, 1999); David Stoll, "Evangelicals, Guerrillas, and the Army: The Ixil Triangle Under Rios Montt," in Harvest of Violence: Maya Indians and the Guatemalan Crisis, edited by Robert M. Carmack (Norman, OK: University of Oklahoma Press, 1988). For recent work on evangelical internationalism see Andrew Preston, "Evangelical Internationalism: A Conservative Worldview for the Age of Globalization," in The Right Side of the Sixties: Reexamining

Conservatism's Decade of Transformation, ed. Laura Jane Gifford and Daniel K. Williams (New York: Palgrave Macmillan, 2012): 221-242.

${ }^{11}$ National Oceanic and Atmospheric Administration, National Geophysical Data Center, "February 4, 1976 Los Amateos Guatemala Earthquake," http://www.ngdc.noaa.gov/hazardimages/event/show/9.

${ }^{12}$ Orlando Olcese, "The Guatemala Earthquake Disaster of 1976: A Review of its Effects and of the Contribution of the United Nations Family," (Guatemala: United Nations Development Programme, 1977): 1.

${ }^{13}$ Russell Chandler, "Church Relief Agencies Move Quickly to Aid Guatemala Earthquake Victims," Los Angeles Times (21 February 1976): A26.

14 Ibid. 
into one of the most Protestant nations in Latin America, a transformation that had profound implications for Guatemalan society and politics. ${ }^{15}$

One week after the disaster, Billy Graham chartered a private plane from Mexico with Latin American evangelist Luis Palau to tour the most devastated areas and offer spiritual solace. The destruction and misery they witnessed overwhelmed them. During a meeting with Guatemalan President Kjell Eugenio Laugerud García, Graham stated that although the Billy Graham Evangelistic Association had sent in large shipments of food, medicine, and clothing, the aid provided to that point was insufficient to meet the tremendous need. He promised to send more. ${ }^{16}$ Yet for Graham and other evangelicals concerned with helping Guatemala rebuild from the tragedy, material assistance alone would not suffice. They believed the nation needed Christian salvation as well. In a statement to the press, Graham declared that despite the devastation, the earthquake could serve a greater purpose and turn out to be a blessing, as the “"tears shed by Guatemalans may be the way to reconciliation with God." ${ }^{17}$ Urging the populace to accept that " "peace can only be found in Jesus Christ," Graham made it clear that he saw the earthquake as a potential catalyst for mass conversion and, therefore, salvation. ${ }^{18}$ Missionminded evangelicals throughout the United States shared Graham's view. The disaster presented a tremendous opportunity for evangelical expansion, and they seized it.

The impulse to send spiritual as well as material aid to help those affected by the disaster reflected core evangelical beliefs about the relationship between evangelization and social action. Regardless of denomination, evangelicals shared a belief that they must engage in missionary

\footnotetext{
${ }^{15}$ The Pew Forum on Religion \& Public Life, Global Christianity: A Report on the Size and Distribution of the World's Christian Population, Pew Research Center (December 2011). Available from: http://www.pewforum.org/files/2011/12/Christianity-fullreport-web.pdf

16 "Declaró Billy Graham Tras su Recorrido," Diario El Imparcial (14 Febrero 1976), Publicación Diario El Imparcial, Serie: La Morgue (recortes de periódicos), GRAHAM, Billy, Ficha: S/7158 (2) 1-9, Ramo: Biográfricos, CIRMA.

${ }^{17}$ Ibid.

${ }^{18}$ Ibid.
} 
work or evangelism to "make disciples of all nations," as Jesus commanded in his Great Commission to the eleven disciples at Galilee. ${ }^{19}$ For premillennialist evangelicals such as Graham, this Great Commission figured prominently into their understanding of eschatology. Premillenialists believed that "Jesus Christ will return personally and visibly, in power and glory, to consummate his salvation and his judgment," as described in the books of Mark, Matthew, Hebrews, Revelation and others. ${ }^{20}$ They interpreted these Scriptures as prophecy and trusted that, upon the fulfillment of biblical predictions, Christ would return to usher in the Kingdom of God on Earth. ${ }^{21}$ World evangelization played a key role in those apocalyptic predictions, as many evangelicals read scriptures such as Matthew 24:14 (“And this gospel of the kingdom will be preached in the whole world as a testimony to all nations, and then the end will come") and Mark 13:10 ("And the good news must first be proclaimed to all nations") as evidence that evangelism must precede the second coming. ${ }^{22}$

In an era fraught with debate over liberation theology and the embrace of a social justice rather than a missionary orientation within Catholicism and mainline Protestant denominations, evangelicals held fast to their commitment to global evangelism. ${ }^{23}$ When religious leaders from 150 countries gathered in Lausanne, Switzerland in 1974 for Billy Graham's International Congress on World Evangelization, the place of social action in the hierarchy of Christian responsibility emerged as a major point of debate. Many Western evangelicals viewed global

\footnotetext{
${ }^{19}$ Mt 28:16-20 (New International Version), "the great commission.” See also Mt 24:14; Mk 13:10, 16:15.

20 "The Lausanne Covenant," in Let the Earth Hear His Voice: International Congress on World Evangelization, Lausanne, Switzerland Official Reference Volume, ed. J. D. Douglas (Minneapolis, MN: World Wide Publications, 1975), 8-9.

${ }^{21}$ Gayraud S. Wilmore, Last Things First (Philadelphia: Westminster Press, 1992), 47-48.

${ }^{22}$ Mt 24:14 (NIV); Mk 13:10 (NRSV), referenced in "The Lausanne Covenant," 9.

${ }^{23}$ Al Tizon, Transformation After Lausanne: Radical Evangelical Mission in Global-Local Perspective (Eugene, OR: Wipf \& Stock, 2008): 54-58; Dana Robert, "The Great Commission in an age of Globalization," in The Antioch Agenda: The Restorative Church at the Margins. Celebrating the Life and Work of Orlando Costas, ed. D. Jeyaraj, R. Pazmino, and R. Petersen (New Delhi, India: Indian Society for the Promotion of Christian Knowledge, 2007): 67; Philip Jenkins, The Next Christendom: The Coming of Global Christianity (Oxford: Oxford University Press, 2007).
} 
efforts to spread the Gospel as the most significant form of social action they could undertake as Christians. ${ }^{24}$ At the Congress, Fuller Theological Seminary professor Donald McGavran argued that "men have no greater needs than to be reconciled to their Father and to walk in the Light." 25 Though he acknowledged the pressing material needs that many faced throughout the world and welcomed Christian efforts to bring about change, McGavran pushed back against "the drive to replace evangelism with social action." ${ }^{26} \mathrm{He}$ argued that salvation and church expansion provided the fundamental building blocks for "a righteous, peaceful society." ${ }^{27}$ From this perspective, which informed evangelical disaster relief efforts throughout the world, there could be no greater salvation for the suffering than salvation in Christ. ${ }^{28}$

In addition to the famous evangelists and major parachurch organizations that delivered assistance to Guatemala, missionaries from a number of small, independent evangelical churches fanned out into the cities and countryside to help the country rebuild and to plant churches. The rapid proliferation of these mostly neo-Pentecostal congregations reshaped not just the religious landscape of Guatemala, but the social and political culture as well. Sociologists and scholars of religion have argued that conversion to Protestantism and, in Latin America specifically, to Pentecostalism, facilitated social mobility among believers and modernization throughout the economy more broadly. ${ }^{29}$ In Guatemala, this proved true in the case of the many neo-Pentecostal

\footnotetext{
${ }^{24}$ Harold Lindsell, "Lausanne 74: An Appraisal," Christianity Today (September 13, 1974), 21.

${ }^{25}$ Donald McGavran, "The Dimensions of World Evangelization," in Let the Earth Hear His Voice: International Congress on World Evangelization, Lausanne, Switzerland Official Reference Volume, ed. J. D. Douglas (Minneapolis, MN: World Wide Publications, 1975), 95.

${ }^{26}$ Ibid, 96.

${ }^{27}$ Ibid.

${ }^{28}$ The ICOWE inspired increased outreach from Western evangelicals and also encouraged indigenous evangelism within Guatemala from Guatemalan religious leaders seeking to evangelize Ladinos and rural Mayans. See The Lausanne Committee for World Evangelization, "Evangelization in Central America Today," World Evangelization Information Bulletin 17 (February 1980), Records of National Religious Broadcasters, Collection 309, Box 101, Folder 13 LCWE Bulletins 1978-1983, Billy Graham Center, Wheaton, IL.

${ }^{29}$ Harvey Cox, Fire from Heaven: The Rise of Pentecostal Spirituality and the Reshaping of Religion in the TwentyFirst Century (Cambridge, MA: Da Capo Press, 1995), 171. Cox notes that conversion to the Pentecostal faith requires an often radical change in lifestyle, as believers must conform to its moral precepts. He argues that their
} 
congregations that sprang up in urban areas following the disaster.

Although the first Protestant missionaries had arrived in Guatemala in 1882, only about 7 percent of the population belonged to a Protestant or evangelical church prior to the 1976 earthquake. ${ }^{30}$ As missionaries and evangelical NGOs streamed into Guatemala to aid the suffering populace, the rate of conversion increased exponentially. According to survey data that researchers at San Carlos University in Guatemala published in 1989, the Protestant population grew by 14 percent between 1976 and 1978, and by 42 percent between 1978 and 1982. By 1982, just over 22 percent of the population belonged to a Protestant church. The rate continued to increase throughout the 1980 s and 1990s. ${ }^{31}$ Pentecostal and neo-Pentecostal denominations accounted for a major share of this growth.

Missiologist Veronica Melander notes that not all of the Protestant expansion that followed in the wake of the earthquake originated from churches that U.S. missionaries planted after the disaster. Many long-established churches took the opportunity that the disaster presented to expand into new territory. ${ }^{32}$ Immediately after the earthquake, the Assemblies of God, which had sent its first missionaries to Guatemala in 1934, shared optimistic reports from

\footnotetext{
"reputation for sobriety, punctuality, and honesty" makes Pentecostals sought after employees. In this manner, the cultivation of the so-called "Protestant work ethic" has prepared such workers to participate in modern industrial capitalism. See also Peter L. Berger, "Introduction: The Cultural Dynamics of Globalization," in Many Globalizations: Cultural Diversity in the Contemporary World, ed. Peter L. Berger and Samuel P. Huntington (Oxford: Oxford University Press, 2002): 8. For the data Berger draws on linking Pentecostalism with social mobility, see Arturo Fontaine Talavera, "Trends Toward Globalization in Chile," in Many Globalizations: Cultural Diversity in the Contemporary World, ed. Peter L. Berger and Samuel P. Huntington (Oxford: Oxford University Press, 2002): 271-274.

${ }^{30}$ Luis Samandú, Claudia Dary Fuentes, and Vitalino Similox Salazar, El protestantismo en Guatemala (Guatemala: Universidad de San Carlos de Guatemala, Dirección General de Investigación, 1989): 61. Most other Guatemalans belonged to the Catholic Church and/or followed traditional Mayan spiritual practices.

${ }^{31}$ Samandú, Fuentes, and Salazar, El protestantismo, 61. The authors noted that this percentage represented over 1.65 million people. Protestant sects continued to grow through the 1980s, comprising nearly 2.7 million, or 31.5 percent of the population, by 1988. Current estimates of the Protestant population in Guatemala range from 25 to 40 percent.

${ }^{32}$ Melander, The Hour of God?, 74.
} 
local evangelists about the potential for revival in the disaster-stricken country. ${ }^{33}$ Throughout the following year, Assemblies of God missionaries launched 200 "Good News Crusades" in Guatemala as part of a campaign — nicknamed "Invasion '77" — to expand the reach of their denomination. ${ }^{34}$ Alongside the crusade activities of larger denominations, many small evangelical churches established themselves in Guatemala City at this time, too. The diversity and range of evangelical expansion efforts made for a vibrant "marketplace" of religion, which helped to attract and retain new adherents. ${ }^{35}$ These factors, along with the influx of funding from evangelicals in the United States post-earthquake, contributed to the continuing spread of U.S.style evangelical Protestantism in Guatemala. ${ }^{36}$

The particularities of U.S. evangelical belief and worship practices ensured that this expansion wrought deep change in Guatemala, reshaping thousands of lives, coalescing with ongoing political change in the country, and solidifying transnational ties with evangelicals in the United States. People suffering from poverty and the destruction in Guatemala found neoPentecostalism attractive for both spiritual and material reasons. Theologian Néstor Medina suggests that in addition to the fact that the Protestant churches proved more efficient than Catholics at providing disaster relief, the message of Pentecostalism resonated with many Guatemalans in the aftermath of the earthquake. ${ }^{37}$ Medina notes that the conversion rate continued to rise in Guatemala even as the inflow of aid tapered off, and as such he suggests: Pentecostalism helped people rebuild their lives and make sense of their reality through

\footnotetext{
${ }^{33}$ Loren Triplett, "Guatemala —Earthquake," Press Statement (4 February 1976), 10-64-14 Guatemala: Guatemala earthquake, 1976 5/5/4 ID: 50135, Flower Pentecostal Heritage Center, Springfield, Missouri (hereafter FPHC).

34 "Pray for Guatemala Crusades," Pentecostal Evangel (13 November 1977): 17.

${ }^{35}$ On the ways in which competition in the "religious economy" leads to higher levels of religious observance, see Roger Finke and Rodney Stark, The Churching of America, 1776-2005: Winners and Losers in Our Religious Economy (New Brunswick, NJ: Rutgers University Press, 2006): 9, 11.

${ }^{36}$ Ibid.

${ }^{37}$ Néstor Medina, "The New Jerusalem versus Social Responsibility: The Challenges of Pentecostalism in Guatemala," in Perspectives in Pentecostal Eschatologies: World Without End, ed. Peter Althouse and Robby Waddell (Eugene, OR: Wipf \& Stock Publishers, 2010): 326.
} 
apocalyptic lenses. The Pentecostal message of the imminent coming of the Lord, war, suffering, and earthquakes as signs of the end times contributed greatly to people flocking to Pentecostal churches. The eschatological message seemed to fit the social and political context. ${ }^{38}$

In addition to the apocalyptic overtones of the disaster itself, neo-Pentecostal churches took advantage of the rush of internal migration from rural villages to Guatemala City that the earthquake jumpstarted. According to Virginia Garrard-Burnett, evangelicals offered these rural immigrants food, shelter, and loans to help them establish themselves in the city-essential assistance that the Catholic Church and local government did not provide. ${ }^{39}$ Evangelical churches "actively encouraged the economic improvement of their members by conflating notions of material and spiritual well-being." 40 With their insistence on sobriety and the inculcation of the so-called Protestant work ethic, conversion to Pentecostalism often led to upward social mobility. ${ }^{41}$ Additionally, the prayer meetings, women's groups, and associations that evangelical churches organized gave migrants a sense of community, which helped counterbalance the otherwise isolating experience of their new urban lives. ${ }^{42}$

The particular form of U.S. Pentecostal worship, with its emphasis on ecstatic expression and the experience of an "unmediated, personal relationship with God," drew immigrants in, yet it also blended syncretically with elements of indigenous spirituality that had persisted in rural

\footnotetext{
${ }^{38}$ Ibid, 327.

${ }^{39}$ Garrard-Burnett, Protestantism, 121-22.

${ }^{40}$ Ibid, 123.

${ }^{41}$ Ibid; Cox, Fire, 171-172; Berger, "Introduction," 8.

${ }^{42}$ Garrard-Burnett, Protestantism, 122; Cox, Fire, 15; Kevin Lewis O'Neill, City of God: Christian Citizenship In Postwar Guatemala (Berkeley: University of California Press, 2010): 23. These authors note that due to its size and organizational structure, the Catholic church could not offer the small-scale, responsive outreach and individualized attention that evangelical groups did. These services proved enormously appealing to newly-arrived migrants, many of whom were nominally Catholic. That Pentecostal worship helped migrants cope with city life was not a new observation; it has been well documented in the sociological literature. Rather it is this phenomenon coupled with the scale of migration that followed the earthquake that made this situation in Guatemala so transformative. For earlier accounts of this phenomenon, see Bryan R. Roberts, "Protestant Groups and Coping with Urban Life in Guatemala City,” American Journal of Sociology 73, no. 6 (May 1968): 753-759, 761.
} 
villages. ${ }^{43}$ This syncretism supplied a comforting familiarity for migrants and aided the vast expansion of neo-Pentecostal churches from the urban core to the rural highlands and beyond. ${ }^{44}$ Significantly, although Pentecostalism spread quickly and became indigenized among rural Mayans, Pentecostal churches in the cities tended to retain an American character and bonds with counterparts in the United States, even as local leaders gradually took over from the original missionaries. ${ }^{45}$ El Verbo, with its ties to the Gospel Outreach Church in California, typified this pattern of urban church growth and connectivity.

\section{Gospel Outreach, the Guatemalan Civil War, and Ríos Montt}

Shortly after the earthquake struck in 1976, Gospel Outreach Reverend Carlos Ramírez led fifteen missionaries and six of their children from the California church to Guatemala City to assist in the reconstruction efforts and to spread the Gospel. ${ }^{46}$ Initially, they focused their efforts on helping local people rebuild their houses. Soon, however, they began to hold regular Bible study meetings in the homes of middle and upper-class residents of Guatemala City. ${ }^{47}$ Ríos Montt joined one of these Bible study groups in 1979 at the urging of a fellow army officer. Ramírez and Jim DeGolyer, another American Gospel Outreach pastor, led the group, which included future Ríos Montt advisors Francisco Bianchi and Álvaro Contreras. ${ }^{48}$ Through these meetings, which involved prayer, close readings of Scripture, and discussions of the personal

\footnotetext{
${ }^{43}$ O’Neill, City, 24; Cox, Fire, 101.

${ }^{44}$ Cox, Fire, 101-102.

${ }^{45}$ Calvin L. Smith, "Pentecostal presence, power and politics in Latin America," Journal Of Beliefs \& Values: Studies In Religion \& Education 30, no. 3 (December 2009): 224-225.

${ }^{46}$ Guatemala Task Force, "Biography of Carlos Ramírez, Pastor of Verbo Christian Church in Guatemala Fact Sheet," Press Release, Undated [ca. 1982-1983], Guatemala in The North American Congress on Latin America (NACLA) Archive on Latin Americana (Wilmington, DE: Scholarly Resources Inc., 1998): roll 19, file 90, frames 907-908; Joseph Anfuso and David Sczepanski, Efrain Rios Montt, Servant or Dictator?: The Real Story of Guatemala's Controversial Born-Again President (Ventura, CA, U.S.A.: Vision House, 1984), 77. Ramírez, a United States citizen of Colombian origin, had joined the Gospel Outreach Church in 1971 and became an ordained minister in the church in 1975.

${ }^{47}$ Cristobal Vargas, “Guatemala: A New Jerusalem?” Latinamerican Press 3 (February 1983): 3-4, in Civil War, Society and Political Transition in Guatemala, Series 5 Roll 13.

${ }^{48}$ Anfuso and Sczepanski, Efrain Rios Montt, 81, 83.
} 
challenges each participant faced, Ríos Montt had a salvation experience and became a "born again" Christian. ${ }^{49}$

Ríos Montt's receptivity to evangelicalism stemmed from personal setbacks linked to government corruption and the ongoing Guatemalan Civil War. ${ }^{50}$ In 1974, after serving in the Guatemalan army for nearly thirty years, at various points as director of the Army's Escuela Politécnica, as brigadier general, and as Army chief of staff, he had run for president on the Christian Democratic ticket. He and his running mate won popular support and the majority of the votes on a platform of moderate reform. Yet rampant electoral fraud at the hands of the extreme right-wing Movimiento de Liberación Nacional (MLN) party denied him his victory. After the stolen election, the Guatemalan Minister of Defense assigned Ríos Montt to serve as a military attaché in Madrid, Spain in order to prevent him from posing a threat to Kjell Laugerud, whose triumph at the polls the MLN and sitting president General Carlos Manuel Arana Osorio had coordinated. ${ }^{51}$ The loss of the presidency and forced exile left Ríos Montt embittered..$^{52}$ Within Guatemala, widespread disaffection over the fraudulent election, coupled with the insufficiency of military reform programs, reignited the guerrilla movement. ${ }^{53}$ In response, General Lucas García, whom Kjell Laugerud handpicked as his successor in 1978, intensified the repression against the guerrillas and indigenous groups, employing death squads to assassinate

\footnotetext{
${ }^{49} \mathrm{Ibid}, 87$. Ríos Montt's wife and children converted as well. Prior to conversion, the family had been Catholic.

${ }^{50}$ In 1954, the CIA and right-wing military leader Carlos Castillo Armas overthrew the democratically-elected Jacobo Arbenz, reversing ten years of popular reforms and unleashing a wave of repression and political instability. The resultant civil war lasted from 1960-1996, during which a succession of right-wing presidents, nearly all hailing from the military, waged a protracted battle against left-leaning insurgents over issues related to land tenure and economic justice. Through a combination of brutal state violence and incremental reform, the military had temporarily succeeded in subduing the insurgency by the early 1970s.

${ }^{51}$ Garrard-Burnett, Terror, 42-43; Stoll, "Guatemala," 28.

${ }^{52}$ United States Defense Intelligence Agency, "Biographic Information on Leader of March 1982 Coup in Guatemala,” March 28, 1982, Confidential Cable, DNSA; Anfuso and Sczepanski, He Gives, 64-81.

${ }^{53}$ Garrard-Burnett, Terror, 34-35, 42.
} 
political enemies and massacring entire Mayan villages indiscriminately. ${ }^{54}$ His government justified these depredations with Cold War ideology, linking the guerrillas with Cuban communism and characterizing guerrilla successes as progress toward totalitarianism and an existential threat to the state. ${ }^{55}$ The state violence further radicalized the populace and earned Guatemala international censure for human rights violations.

While the situation in Guatemala deteriorated, Ríos Montt grew increasingly frustrated with his life in exile. In 1977, the Escuela Politécnica that he had attended as a cadet and later led as its director invited him to attend the inauguration of its new facilities. ${ }^{56} \mathrm{He}$ used the invitation as a means to return home permanently, informing government officials that he would not resume his post in Madrid. The minister of defense placed him on inactive military status, and Ríos Montt retired to private life, where he nursed hopes that another opportunity to run for president would present itself. ${ }^{57}$ Not long after, he began attending el Verbo prayer meetings.

In their recollections of Ríos Montt's conversion experience, church elders suggested that the general found relief from his bitterness over the lost election and exile in the evangelical teachings and lively spiritual community of $e \mathrm{Verbo} .{ }^{58}$ These fundamental Pentecostal elements hewed closely to those of the Gospel Outreach Church, which Ramírez had modeled el Verbo after in message, worship style, and mission when he established his ministry in Guatemala in 1976. Gospel Outreach had grown out of the Jesus Movement that swept the United States in the late 1960s and early 1970s, attracting disaffected youth who found the emotionality of Christian

\footnotetext{
${ }^{54}$ Ibid, 45, 48-49.

${ }^{55} \mathrm{Ibid}, 27-30$. As Garrard-Burnett notes, many of the leftist guerrilla groups did have links to Cuba.

${ }^{56}$ Damage from the earthquake had forced the closure of the original school buildings. Escuela Politécnica, "Centenaria y Gloriosa Escuela Politécnica," http://www.politecnica.edu.gt/historia.html and "Directores," http://www.politecnica.edu.gt (accessed 3 September 2013); Anfuso and Sczepanski, He Gives, 78-79.

${ }^{57}$ Anfuso and Sczepanski, He Gives, 79-80.

${ }^{58} \mathrm{Ibid}, 86-87$. In interviews, Ríos Montt stated that his conversion allowed him to shed his bitterness because he came to "see God's hand" in the events of 1974. Harry Genet and Stephen Sywulka, "You Heard it Right: The Dictator is an Evangelical Christian," Christianity Today 26, no. 8 (April 23, 1982): 33.
} 
revivals, emphasis on the Holy Spirit, and simple, communal living an appealing alternative to mainstream culture. ${ }^{59}$

Jim Durkin, a California real estate agent and evangelical preacher, had founded Gospel Outreach after he began ministering to a small group of Jesus People who had rented one of his buildings for use as a "coffee house ministry." 60 The church grew rapidly as hundreds of people, including a young Carlos Ramírez, flocked to the Lighthouse Ranch and other properties that Durkin had acquired for the fledgling church. ${ }^{61}$ There, according to Gospel Outreach materials, "many of them found the Lord Jesus Christ as their Savior and decided to stay." 62 The vision that Durkin articulated to his followers entailed three core evangelical tenets, drawn from Scripture: "to preach the gospel to every creature," to "have the same unity with each other as the Lord Jesus had with His Father" in order to "effectively carry out God's work," and "to be individually conformed to the image of Christ."63

These deeply held evangelical beliefs about the necessity of Christian witness to fulfill the Great Commission motivated Durkin and the other leaders of Gospel Outreach to propagate their model of worship throughout the United States and the rest of the world. Within a decade of its founding, Gospel Outreach had established ministries in 44 U.S., European, and Latin American cities_-including el Verbo in Guatemala. ${ }^{64}$ The promise of individual salvation, energetic worship, and tight-knit community that attracted Ríos Montt brought a number of other

\footnotetext{
${ }^{59}$ The Jesus Movement blended Charismatic and evangelical forms of Christianity with the hippie counterculture of the 1960s. Patrick Allitt, Religion In America Since 1945: A History (New York: Columbia University Press, 2003): 133-137.

${ }^{60}$ Guatemala Task Force, "Gospel Outreach Fact Sheet," Press Release, Undated [ca. 1982-1983], Guatemala in The North American Congress on Latin America (NACLA) Archive on Latin Americana (Wilmington, DE: Scholarly Resources Inc., 1998): roll 19, file 90, frame 892.

${ }^{61}$ Ibid, frames 892-893; Paul Goepfert, "The Lord and Jim Durkin: How Eureka became the religious capital of Guatemala," Data Center Files (February 1983), Civil War, Society and Political Transition in Guatemala, Series 5 Roll 13.

${ }^{62}$ Guatemala Task Force, "Gospel Outreach Fact Sheet," frame 893. During the mid-1970s, Gospel Outreach evolved into a non-denominational neo-Pentecostal church.

${ }^{63} \mathrm{Ibid}$, frames 893-895.

${ }^{64}$ Ibid, 895; Goepfert, "The Lord," 1.
} 
local residents, including prominent business and political leaders, into the fold. By 1982, el Verbo boasted 1,200 members, with an additional 450 children enrolled in the affiliated school. ${ }^{65}$ While el Verbo engaged in efforts to expand throughout the Guatemalan countryside and into other Latin American countries, it retained close ties with its parent church in California. The relationship extended beyond communications between the original Gospel Outreach missionaries and Gospel Outreach leaders, and a network of intellectual exchange between Guatemalan evangelical converts and their U.S. counterparts flourished. Indeed, in 1979, Ríos Montt visited the California church with his wife and daughter, meeting with the founders and speaking at church services. ${ }^{66}$ Encouraging reciprocal bonds of kinship with members of its missionary churches, Gospel Outreach embraced a policy of global engagement aimed at building a cohesive community of believers that transcended national boundaries - a goal that many U.S. evangelicals shared.

As one of hundreds of similar Guatemalan evangelical churches, el Verbo stood out mostly for its relationship with Ríos Montt, yet the political connections and social mobility of its members exemplified the socio-political realignment that emerged from evangelical expansion in Guatemala during this period. Core theological and political predilections led evangelical Protestants, particularly neo-Pentecostals such as the followers of el Verbo, into a de facto alliance with the right-leaning Lucas government. With their deep commitment to evangelism, rooted in eschatological imperatives as well as to their faith in the centrality of individual salvation, evangelicals focused first on otherworldly, rather than worldly, matters. Ostensibly, this meant they avoided politics. In practice, however, it led them to support the status quo, at least tacitly. Like their counterparts in the United States, many Guatemalan

\footnotetext{
${ }^{65}$ Guatemala Task Force, "Biography of Carlos Ramírez," frame 908.
}

${ }^{66}$ Anfuso and Sczepanski, Efrain Rios Montt, xiii. 
evangelicals rigidly opposed communism. Communist ideology and objectives stood in direct opposition to evangelical ideology and objectives, as they posed a threat to evangelism and salvation through faith in Jesus Christ. As such, most evangelicals supported government efforts to quell the insurgency. ${ }^{67}$

When the growing frequency and ruthlessness of army massacres between 1980 and early 1982 led to increased public support for the guerrillas and greater solidarity among indigenous and leftist religious groups, the ruling regime looked to the rapidly expanding evangelical sects to shore up political support. By the time the campaign for the 1982 presidential election began, Protestants comprised nearly 20 percent of the Guatemalan population, a sizeable potential voting bloc. President Lucas's hand-selected successor, General Ángel Aníbal Guevara, courted them. He donated money to American missionary churches and appeared at an evangelical revival held at the national soccer stadium, where he promised the 50,000 people in attendance that he would give "special consideration to evangelicals in his administration" if elected. ${ }^{68}$ With the army overseeing the election, Lucas ensured Guevara's victory. When the other candidates and their supporters protested the blatant election fraud, the regime swiftly and violently repressed their dissent. ${ }^{69}$

Yet Lucas could not stifle the seething anger that the Guatemalan people, including those in the military, felt over the election and the country's state of affairs. ${ }^{70}$ Within weeks, a cadre of young army officers staged the coup that removed Lucas from power and placed Ríos Montt at

\footnotetext{
${ }^{67}$ Most, though certainly not all. Progressive and leftist evangelicals did have a voice in Guatemala, and some worked with leftist evangelical groups in the United States, such as the Association for Public Justice. For recent work on the evolution of a radical evangelical left in Central America in this period, see Rodney A. Coeller, Beyond the Borders: Radicalized Evangelical Missionaries in Central America from the 1950s through the 1980s (unpublished doctoral dissertation, 2012), American University, Washington, D.C.

${ }^{68}$ Cor Bronson, "Guatemala's Coup: A Protestant's Perspective," (1982): 3, in Civil War, Society and Political Transition in Guatemala, Series 5 Roll 12.

${ }^{69}$ Ibid.

${ }^{70}$ Washington Office on Latin America, “The Military Coup in Guatemala of the 23 March 1982," Press Release (30 March 1982): 1, in Civil War, Society and Political Transition in Guatemala, Series 5 Roll 13.
} 
the head of the new ruling junta. Their demands made clear that they sought, above all else, to reinstate free and fair elections in Guatemala. After taking power, they announced that "the junta would govern for 60 days during which time it will supervise national elections and no military candidates would be permitted to stand for office." 71

\section{Bringing God and Evangelical Aspirations to Guatemalan Governance}

Although the young officers did not realize that Ríos Montt had converted to evangelical Christianity when they asked him to head the junta, the soaring religious rhetoric that animated his first speech to the nation on the evening of March 23, 1982, made his new outlook apparent. Ríos Montt's proclamations after the coup, and in the months that followed, seemed to indicate to U.S. and Guatemalan evangelicals his intentions to improve life in his country and help fulfill the Great Commission by turning Guatemala to God. Dressed in military fatigues and flanked by the other junta leaders at his first press conference on the evening of the coup, Ríos Montt told the assembled reporters, "I am trusting God, my Lord and my King, to enlighten me because he is the only one who gives or takes away authority." 72

\section{[FIGURE 2]}

Having thus expressed his belief that divine will had placed him in power, he pledged to the people of Guatemala that "he and his two junta partners have a mission to revitalize the nation's moral values, extend more human rights, and cut down on corruption." ${ }^{\text {73 }}$ In keeping with evangelical doctrine concerning individual salvation, he stressed that each Guatemalan must work toward improving the country, noting that only "once there is peace in your heart...there

\footnotetext{
${ }^{71}$ Chapin, “Coup Sitrep No. 5,” 2.

72 Anderson and Hart, "Headline," NBC Evening News.

${ }^{73}$ Bonnie Anderson and John Chancellor, "Headline: Guatemala," NBC Evening News (March 24, 1982); Frederic Chapin, United States Embassy, Guatemala to United States Department of State, "Piedra/Carbaugh Visit: Impressions of President Rios Montt," May 19, 1982, Confidential Cable 003591, DNSA.
} 
will be peace in society." 74 He reiterated these themes in weekly sermons broadcast throughout Guatemala on Sundays, urging his countrymen to live according to Christian morality and to spread the Gospel so that they could "share the joy of knowing God.",75

For their part, many Guatemalans viewed the coup and the new ruling triumvirate cautiously. Despite his reputation as a political moderate and his identity as a "born again" Christian, Ríos Montt was still a brigadier general in the army. The other junta leaders, Maldonado Schaad and Gordillo Martínez, served as a general and a colonel, respectively. The Washington Office on Latin America and the Catholic Iglesia Guatemalteca en el Exilio (IGE) argued that, although Guatemalans welcomed the end to urban violence that Ríos Montt effected after taking power, little else had changed:

The oppressive apparatus of the army is still in place and there is absolutely no indication that the Junta is about to introduce the far-reaching reforms that the country needs to remove the social, economic and political contradictions that condemn the vast majority of the population to a life of degradation and poverty. ${ }^{76}$

Indeed, many Guatemalan Catholics railed against Ríos Montt's religious rhetoric. ${ }^{77}$ Decrying

Ríos Montt as a false prophet, leftist Catholic and Christian organizations, including IGE, Comite Pro-Justicia y Paz de Guatemala, and Cristianos Revolucionarios 'Vicente Menchú,' cultivated a steady stream of opposition to the general. ${ }^{78}$

Nevertheless, Ríos Montt's rise to power inspired a dizzying sense of possibility among

\footnotetext{
${ }^{74}$ Efraín Ríos Montt, quoted in Genet and Sywulka, "You Heard it Right," 34.

75 "Ríos Montt se dirige a los guatemaltecos sobre el tema de las presentes navidades," Prensa Libre (20 December 1982), Publicación Diario El Imparcial, Serie: La Morgue (recortes de periódicos), Presidente: Gral. Rios Montt (1982-1983) Ramo: Gob, CIRMA.

${ }^{76}$ Washington Office on Latin America, "The Military Coup," 2; Iglesia Guatemalteca en el Exilio. "El Golpe de Estado, Otra Fraude Contra el Pueblo de Guatemala," Boletin, no. 11 (Febrero-Marzo 1982): 9-11, in Civil War, Society and Political Transition in Guatemala, Series 5 Roll 62.

77 “Así lo dijo," Prensa Libre (27 December 1982).

${ }^{78}$ Frente Popular 31 de Enero, "Hablan los Cristianos,"; Comite Pro-Justicia y Paz de Guatemala, "Ríos Montt, Falso Profeta" (Guatemala: Enero 1983), Archivo del Comite Holandes de Solidaridad con Guatemala, Cartapacio No. 33 Justicia y Paz II CIRMA; "Rios Montt: Falso Profeta; Coordinadora Cristiana de Solidaridad con la Lucha del Pueblo de Guatemala," Crie Documentos Guatemala 4 (Septiembre, 1982): 10-11, Archivo de la Coordinadora Alemana de Solidaridad con Guatemala. Cartapacio No. 156 Coleccion Infostelle Del 13.01.06 Al 13.01.07, CIRMA.
} 
evangelicals living in Guatemala and the United States, stirring tremendous excitement and expectation about his potential to further evangelical aims. Evangelicals took his statements of faith at face value and believed, earnestly, that God had chosen Ríos Montt to lead Guatemala to advance evangelism — which they saw as the only tenable solution to Guatemala's struggles. ${ }^{79}$ Missionaries writing home to friends, family, and fellow church members in the United States declared Ríos Montt a "spirit-filled Christian" and "born-again believer," calling on their coreligionists to pray that his ascension would win new souls to Christ. ${ }^{80}$ In Gospel Outreach's newsletter Radiance Monthly, church founder Jim Durkin explained the significance of Ríos Montt's leadership from an evangelical perspective:

... we believe that in Guatemala - through prayer and offensive spiritual warfare against the enemy - Satan and his prince (principality) have been toppled. I believe that if we continue in prayer there is tremendous opportunity in Guatemala to show the life and power of Jesus Christ. Justice, prosperity, and blessings can come to a hurting people who are crying out for help. Christ Jesus Himself is that help. ${ }^{81}$

Standing in front of a map of Latin America on the 700 Club one week after the coup, Pat Robertson made a similar plea, intoning, "God we pray for Ríos Montt, your servant, Lord that you would cover him. . . Lord we thank you that your spirit is moving in Guatemala. And we pray right now, heavenly father, for this great nation in Jesus' holy name." 82

U.S. evangelicals saw in Ríos Montt a divinely ordained opening for increased evangelism in the predominantly Catholic countries of Central America. They lavished him with financial support and provided access to political elites in the United States, inspiring his

\footnotetext{
${ }^{79}$ El Verbo elder Henry Gómez framed these struggles using the language of spiritual warfare, noting in an interview, “' $[\mathrm{we}]$ aren't fighting a battle of flesh, blood and bone. We're combating the hordes that invade the spirit." This notion resonated deeply with evangelicals in the United States. Henry Gómez, interview with Julia Preston, in Julia Preston, "God and War in Guatemala," Rolling Stone (13 May 1982): 24.

${ }^{80} \mathrm{Jim}$ and Jean Woolsey, newsletter, May 1982, Assemblies of God World Missions Archives, Guatemala (19801989), FPHC.

${ }^{81}$ Jim Durkin, “A Letter From..." Radiance Monthly (April 1982): 1, in Civil War, Society and Political Transition in Guatemala, Series 5 Roll 13.

${ }^{82}$ CBS Reports: Guatemala, CBS, September 9, 1982. This news report includes a clip from the 700 Club which aired one week after the coup, from which this quote was drawn.
} 
confidence that they would underwrite his policies. Indeed, he told U.S. Ambassador to

Guatemala Frederic Chapin that he expected U.S. Christians would send him a billion dollars in development aid. ${ }^{83}$

In this manner, the evangelicalism that flourished after the 1976 earthquake offered Ríos Montt a useful moral language for distinguishing himself from past regimes while also connecting him with new allies in the United States eager to aid him in his fight against the same "communist insurgents" whom his predecessors had targeted. These relationships moved to the fore as Ríos Montt developed strategies to reform his government, extract military aid from the United States, and defeat the insurgency.

\section{Ríos Montt, Ronald Reagan, and the Evangelical Connection}

When Ríos Montt took power in March 1982, he looked to the leaders of his church for spiritual, personal, and professional guidance. He appointed el Verbo elders Francisco Bianchi and Álvaro Contreras executive secretary and secretary of public relations, respectively, vital positions that allowed them privileged access to him and significant policy influence.

Referencing their participation in meetings with embassy staff, Ambassador Chapin noted, "it was evident not only at the dinner but at the meeting with the congressional staffers ... that the two young church leaders play an important role in molding President Rios Montt's views and policies." ${ }^{\prime 4}$ Although Chapin bristled at their religious rambling, the general believed their appointments would help him instill morality in the government. ${ }^{85}$

Ríos Montt aspired to govern Guatemala with the Bible in mind. He shared the view of

\footnotetext{
${ }^{83}$ Chapin, "Piedra/Carbaugh Visit," (May 19, 1982), 2; Frederic Chapin, United States Embassy, Guatemala to United States Department of State, "Congressional Staff Del Ofnwoodward [sic], Ross and Cameron Have Dinner Meeting with Junta President Rios Montt and Aides Bianchi and Contreras," May 20, 1982, Confidential Cable 003640, DNSA.

${ }^{84}$ Chapin, "Piedra/Carbaugh Visit," (May 19, 1982), 6.

${ }^{85}$ Chapin, "Congressional Staff," (May 20, 1982).
} 
American el Verbo pastor Jim DeGolyer, who noted, “"there is an amazing amount of guidance that the Bible gives kings, heads of state, in how they should rule." "86 Ríos Montt utilized the teachings of DeGolyer and other el Verbo advisers in his speeches and sermonettes, mused on them in discussions with staffers and officials from the U.S. government, and incorporated them into his domestic policies. ${ }^{87}$ Soon after coming to power, he launched an anti-corruption program that he named "Project David," in reference to the biblical King David of Israel, whom he regarded as a virtuous ruler. ${ }^{88}$ As part of this program, he called on all government officials to pledge "No robo. No miento. No abuso," or "I will not steal. I will not lie. I will not abuse." $89 \mathrm{He}$ also drew attention to his efforts to root out and prosecute corrupt officials. ${ }^{90}$

U.S. evangelical magazines and newspapers praised the president for "Project David," offering it as concrete evidence of the sincerity of his promise to bring justice and Biblical rule to his country. ${ }^{91}$ Within Guatemala, the anti-corruption measures and weekly sermonettes led to a rapid decline in crime, political repression, and death squad activity in urban centers. ${ }^{92}$ According to Virginia Garrard-Burnett, these initiatives “contribut[ed] to urban residents' sense of personal safety and thus len[t] social support to the Ríos Montt regime, especially among the urban middle and upper classes.. ${ }^{93}$ Evangelicals, as well as the U.S. government, seized on these improvements as a sign that Ríos Montt intended to honor his pledge to promote human rights in

\footnotetext{
${ }^{86}$ Raymond Bonner, "Guatemala Junta's Chief Says God Guides Him,” New York Times (10 June 1982): A9.

${ }^{87}$ Ibid; Jim DeGolyer, interview by Ed Rabel, CBS Reports: Guatemala, CBS, September 9, 1982; Anfuso and Sczepanski, Efrain Rios Montt, 151; Jim DeGolyer, interview by Jim Lehrer and Charlene Hunter Gault, PBS, MacNeil/Lehrer Report, October 25, 1982.

${ }^{88}$ Ibid.

${ }^{89}$ Anfuso and Sczepanski, Efrain Rios Montt, 151; Jim DeGolyer, interview by Jim Lehrer and Charlene Hunter Gault, PBS, MacNeil/Lehrer Report, October 25, 1982.

${ }^{90}$ Council on Hemispheric Affairs, "COHA's Interim Human Rights Report on Guatemala: March 1982 September 1982," (28 September 1982), Colección de Robert Trudeau sobre Politica de Guatemala, Serie: Documents, Document RHT 829, CIRMA.

${ }^{91}$ Patricia Hollis, "Save Guatemala, Save America!" Mission to America (November, 1982): 3, ID \#119015 WHORM: Subject File, Ronald Reagan Library; Sandra M. Rowland, "Guatemala: A first-hand view of government fighting to restore the confidence of people," Save Our World 22, no. 2 (Spring 1983): 3.

${ }_{92}^{92}$ Garrard-Burnett, Terror, 19.

${ }^{93}$ Ibid; U.S. Director of Intelligence, President Jose Efrain Rios Montt, 5.
} 
Guatemala. $^{94}$

Yet Guatemalans whom he regarded as subversive or as communist sympathizers remained outside of his moral compass. During a post-coup press conference, Ríos Montt growled angrily that his enemies should lay down their arms immediately, as "anyone who is outside the law will be executed." ${ }^{95}$ As the violence in the cities where the mostly-Ladino population resided declined in the first months of Ríos Montt's government, the Guatemalan army moved with devastating efficiency in the rural highlands, systematically killing guerrillas and Mayan civilians. ${ }^{96}$ After offering the guerrillas a one month amnesty period in May, Ríos Montt launched Fusiles y Frijoles ("Rifles and Beans"), the first phase of his Victoria 82 counterinsurgency program, on June 20, 1982. Under this program, the government assessed Guatemalan villages to determine the loyalty of the residents, classing them white for "friendly," red for "enemy," or pink for those "of uncertain allegiance." 97 According to reports, those who supported the government received food, housing and other forms of government largess; those perceived as foes met with "whatever force [was] considered necessary." 98 The army occupied "red" villages, killed suspected guerrillas, and forcibly relocated any remaining residents to "strategic" villages. ${ }^{99}$ After the pacification program took effect and the guerrilla forces started to retreat in September 1982, the army returned residents to the abandoned hamlets-re-

\footnotetext{
${ }^{94}$ Missionary News Service, "Guatemala Junta Leader a Christian," Missionary News Service 29, no. 9 (1 May 1982), Records of National Religious Broadcasters - Collection 309, Box 103, Folder 1, Missionary News Service 1980-1982, Billy Graham Center Archives, Wheaton, IL; National Security Council, "President's Trip to Latin America," Meeting Minutes (23 November 1982), folder "NSC 0006723 November 1982 [President's Trip] Box 91284," Executive Secretariat: Meeting Files NSC 56-70, Box 7, Ronald Reagan Library.

${ }^{95} \mathrm{Jim}$ Lehrer and Charlene Hunter Gault, PBS, MacNeil/Lehrer Report, October 25, 1982.

${ }^{96}$ Ed Rabel, CBS Reports: Guatemala, CBS, September 9, 1982; Frederic Chapin, United States Embassy, Guatemala to United States Department of State, "Violence and Human Rights Report: April 1982," June 3, 1982, Confidential Cable 003956, DNSA.

${ }^{97}$ Bureau of Intelligence and Research (INR), "Guatemala's Guerrillas Retreating in the Face of Government Pressure," Secret Report (3 March 1983): 7, reproduced in Declassified Documents Reference System (hereafter DDRS) (Farmington Hills, MI: Gale, 2013), Document Number: CK3100695455.

${ }^{98}$ Ibid, 1.

${ }^{99}$ Ibid, 7; Garrard-Burnett, Terror, 19.
} 
christened "model villages" - and increased the use of civilian patrols to continue the fight against the insurgency. ${ }^{100}$

Although human rights watch groups raised concerns about Ríos Montt's military strategy, U.S. foreign policy makers and the Reagan administration cautiously embraced his leadership, finding his religiously-infused rhetoric moderate in comparison to previous regimes and his commitment to fighting the "communist insurgency" encouraging. ${ }^{101}$ But tensions between the two governments arose from congressional opposition to providing any military aid to Ríos Montt—specifically its refusal to sell his government the spare helicopter parts it needed to wage war against the guerrillas in the remote, mountainous regions of Guatemala. ${ }^{102}$ In response to Congressional intransigence, evangelicals in the United States and Guatemala facilitated direct meetings between the regime and U.S. government officials, and conducted a public relations campaign to counter the negative impressions that members of Congress and the American public held about the troubled Central American nation.

In an effort to improve bilateral relations, evangelicals from the United States invited Francisco Bianchi to attend a meeting at the home of William Middendorf, the U.S. Ambassador to the Organization of American States and a fellow believer, in June 1982. ${ }^{103}$ They also invited Ambassador Chapin, Reagan cabinet members Edwin Meese and James Watt, evangelical leaders Pat Robertson and Jerry Falwell, Gospel Outreach member Bob Means, and a handful of

\footnotetext{
${ }^{100}$ Bureau of Intelligence and Research, "Guatemala's Guerrillas," 7; Garrard-Burnett, Terror, 20.

${ }^{101}$ George P. Shultz to Ronald Reagan, "Your Meeting with Guatemalan President Rios Montt on December 4 [Includes Talking Points]," Secret Memorandum, November 20, 1982, DNSA; Fred Ikle to Caspar Weinberger, Department of Defense Memo, (20 December 1982), DDRS, Document Number: CK3100664307; Frederic Chapin, United States Embassy, Guatemala to United States Department of State, "Analysis of Rios Montt Government after Eleven Months," February 18, 1983, Confidential Cable 001353, DNSA.

${ }^{102}$ Frederic Chapin, United States Embassy, Guatemala to United States Department of State, "Meeting between President Reagan and President Rios Montt," November 18, 1982, Top Secret Cable 008703, DNSA.

${ }^{103}$ Donna Eberwine, "To Ríos Montt, With Love Lift," The Nation 236, no. 8 (February 26, 1983): 238; Rabel, Guatemala, CBS, September 9, 1982; Goepfert, "The Lord"; Jack Anderson, "Latin Strongman May Embarrass Reagan, Falwell," The Washington Post (29 September 1982): P Md. 17.
} 
other evangelicals. ${ }^{104}$ At the dinner, they brainstormed ways to help Ríos Montt. In addition to direct military aid, Pat Robertson proposed coordinating a "Christian relief strategy" with evangelicals in Guatemala. Aiding Guatemalan villagers whom the army had relocated with building materials, medical care, food, and other donated goods would buttress the counterinsurgency efforts and shore up support for the regime among people living in the rural highlands. ${ }^{105}$ After the meeting, the participants worked with key players in the evangelical community and the government "to launch a national campaign to help Guatemala which will also counter misinformation about the government." ${ }^{106}$ Bianchi and Álvaro Contreras networked with evangelical leaders, meeting privately with Jerry Falwell and Pat Robertson, building relationships with key members of the National Religious Broadcasters, and attending the 1982 Washington Rally for Jesus. ${ }^{107}$

As the evangelical network within the United States sprang into action, it marshaled supporters and funds from the religious, business, and political communities within which it operated. According to The Nation, Pat Robertson proved particularly influential as a spokesman for Ríos Montt; his televised "appeals for prayers and financial support for the regime.... resulted in a flood of letters to the White House demanding U.S. military aid for Guatemala."108 Building on Robertson's momentum, el Verbo pastor Carlos Ramírez, who served as unofficial advisor to Ríos Montt, returned to the United States at the president's request to appeal directly

\footnotetext{
${ }^{104}$ Ibid.

${ }^{105}$ Letter, Robert M. Pittenger to Edwin Meese, 18 August 1982, ID \#094920 CO060, WHORM: Subject File, Ronald Reagan Library. Pittenger, a member of Campus Crusade for Christ, attended the meeting.

${ }^{106}$ Ibid. Those involved included Billy Graham, Bill Bright of Campus Crusade for Christ, Senator Roger Jepsen, Congressman Jack Kemp, and Senator Bill Armstrong.

${ }^{107}$ Jose Efrain Rios Montt to Dr. Jerry Falwell, July 2, 1982, FAL 5-7 Series 1 Folder 1, Correspondence with Foreign Political Leaders: 1980-1984, Liberty University Archive, Lynchburg, VA; Ben Armstrong to General Jose Efrain Rios Montt, 7 December 1982, Records of National Religious Broadcasters - Collection 309, Box 63, Folder 3, International Banquet/Guests '83 Convention, Billy Graham Center Archives, Wheaton, IL.

${ }^{108}$ Eberwine, "To Ríos Montt," 238.
} 
to American Christians. ${ }^{109}$ Fundraising letters from his organization, Love Lift International, emphasized that supporting Ríos Montt's regime would hasten global evangelism, bring freedom to the Guatemalan people, and help defeat communism in the region. ${ }^{110}$

These promises resonated with U.S. evangelicals. In September, Ramírez met with pastors in California to establish the Guatemalan Task Force, which worked as the American "base of support" for his organization. ${ }^{111}$ This group asserted that "God is the Author of the tremendous changes taking place today in Guatemala," and affirmed their commitment "to support the spiritual revival and the peaceful socio-economic revolution that revival is bringing about," noting "the whole nation of Guatemala will benefit as a result." 112 They partnered with Youth with a Mission, a major missionary organization founded in 1960, to gather and deliver tools, medicine, clothing, food, and other supplies to the poor and displaced in Guatemala. ${ }^{113}$ Pat Robertson informed viewers of the $700 \mathrm{Club}$ that the donated materials would help indigenous refugees who had fled their villages to escape guerilla depredations; without support, Robertson alleged, communist forces would overrun Guatemala. ${ }^{114}$ Congressman Jack Kemp endorsed these initiatives and warned about the consequences of failing to provide Ríos Montt with aid. ${ }^{115}$ By the end of 1982, evangelical efforts to encourage the Reagan administration to push Congress to extend military aid to Guatemala began to bear fruit. In early December, Ríos Montt

\footnotetext{
${ }^{109}$ Guatemala Task Force, "Biography of Carlos Ramírez,” frames 907-908.

${ }^{110}$ Carlos Ramírez, "God's miracle in Guatemala has opened a door..." International Love Lift fundraising letter (9 January 1982), reprinted in El Parcial "Las sectas protestantes en Centroamérica," una documentacion de prensa 29, (Octubre de 1991): 105-106, Coleccion Infostelle, Del 23.02.07 al 23.03.01, Signatura 240, CIRMA.

${ }^{111}$ Guatemala Task Force, "Guatemala Task Force Information Sheet," undated [ca. 1982], Guatemala in The North American Congress on Latin America (NACLA) Archive on Latin Americana, roll 19, file 90, frame 901.

112 Ibid.

${ }^{113}$ Ibid, frame 902.

${ }^{114}$ Pat Robertson, 700 Club, CBN, January 31, 1983. The Ríos Montt regime routinely claimed that the guerrillas bore the responsibility for the mass killings and displacement of rural Guatemalans from their villages; outside of supporters for the regime, the bulk of the extent evidence exposes the speciousness of these allegations.

115 Jack Kemp, letter, July 30, 1982, reprinted in CounterSpy (March-May 1983): 49, Archivo de la Coordinadora Alemana de Solidaridad con Guatemala, Cartapacio No. 156, Coleccion Infostelle Del 13.01.06 Al 13.01.07, CIRMA.
} 
and Reagan met in Honduras, the last stop on Reagan's tour of Latin America. ${ }^{116}$ During an NSC planning meeting prior to the trip, Secretary of State George Shultz had summed up the cautious optimism surrounding Ríos Montt that had developed within the administration, telling Reagan, "I have my fingers crossed on this one. We must make the effort to encourage movement toward democracy; they are doing better now than they have for a long time. But, don't throw your arms around him." 117 The NSC stressed to Reagan that Ríos Montt represented a significant break from past regimes. Reagan's advisors underscored the importance of reassuring the Guatemalan leader that the United States supported him, yet they also instructed:

He must understand that the GOG [Government of Guatemala] image abroad is so bad that it is difficult for the democratic countries, including the United States, to convince their legislatures to appropriate assistance. We should encourage him to continue the human rights progress, which will help us in our effort to convince the Congress that the GOG and USG share a common objective in defeating the guerrillas. ${ }^{118}$

At the meeting, Ríos Montt gave President Reagan an overview of his programs and reform efforts, emphasizing the progress his regime had made toward protecting human rights. ${ }^{119}$ He provided Reagan and Shultz a folder of documents entitled, "Este Gobierno Tiene el Compromiso de Cambiar" ("This Government has an Obligation to Change"), which included descriptions of his government's policies and transcripts of his major speeches — all of which referenced his faith in God and its role in his efforts to create a new Guatemala. ${ }^{120}$ After affirming the Guatemalan government's commitment to bringing "peace, reform, economic

\footnotetext{
116 "Summary Schedule of the President's Trip to South and Central America November 30 - December 4, 1982," folder "Trip of President Reagan to Brazil, Colombia, Costa Rica and Honduras, 1982 (Binder) (1)," Box 5, William Sittmann Files, Ronald Reagan Library.

${ }^{117}$ National Security Council, "President's Trip to Latin America," 5.

${ }^{118}$ National Security Council, "Supplementary Issues and Objectives for the President's Visit to Central America," folder "NSC 0006723 November 1982 [President's Trip] Box 91284," Executive Secretariat: Meeting Files NSC 56-70, Box 7, Ronald Reagan Library.

${ }^{119}$ Frederic Chapin, American Embassy Guatemala to U.S. State Department, Draft Memorandum of Conversation: Bilateral Between President Reagan and the President of Guatemala, Rios Montt (6 December 1982), folder "Guatemala, Vol. I, 1/20/81 - 7/31/84 [2 of 5]," Executive Secretariat, NSC: Country File, Latin America, Box 52, Ronald Reagan Library.

${ }^{120}$ Ibid.
} 
progress and democracy" to the country, Ríos Montt delved into the details of fusiles y frijoles and his counterinsurgency strategy, casting both as positive steps toward providing for the poor. ${ }^{121}$ He stated that he planned to use the spare helicopter parts he sought from the United States to engage in "humanitarian work such as airlifting food to Indian farmers who have fled from their homes for fear of violence by subversive forces, the transportation of brigades of doctors and social workers who provide services to refugees, and other comparable tasks." 122 [FIGURE 3]

In this manner, Ríos Montt sought to persuade Reagan of his desire to win their shared battle against communism. He repeated what he and his evangelical proponents in the United States had stressed for months: reports from international human rights organizations and the news media about massacres, kidnappings, torture, and the mass displacement of indigenous Guatemalans misrepresented the situation on the ground. The guerrillas committed these crimes, Ríos Montt argued, not the army. ${ }^{123}$ Despite overwhelming evidence to the contrary, Reagan seemed to take the general at his word, calling him "a man of great integrity." 124 In reality, during the seventeen months Ríos Montt led Guatemala, nearly 86,000 people—mostly Maya-

\footnotetext{
${ }^{121}$ General José Efraín Ríos Montt, "Mensaje del presidente Rios Montt, durante su primer ano del gobierno," (December 1982): 1, Archivo de Inforpress Centroamerica, Serie: Documentos, Documento 1512, CIRMA. This document was included in the "Este Gobierno Tiene el Compromiso de Cambiar" folder.

122 Ibid, 2-3.

${ }^{123}$ Fred Francis and Chris Wallace, "Headline: Reagan/Guatemala Aid," NBC, Evening News, 5 December 1982. For an earlier interview wherein Ríos Montt attributes massacres and displacement to the guerrillas rather than to his army, see Efraín Ríos Montt, interview with Ed Rabel, CBS Reports: Guatemala, CBS, September 9, 1982.

${ }^{124}$ The extant evidence on the Guatemalan army's responsibility for the killings, kidnappings, and displacement is staggering. See Daniel Rothenberg, Memory of Silence: the Guatemalan Truth Commission Report (NY: Palgrave Macmillan, 2012); Recovery of Historical Memory Project, Guatemala: Never again! The Official Report of the Human Rights Office, Archdiocese of Guatemala, (Maryknoll, NY: Orbis Books, 1999); Tribunal Permanente de Los Pueblos, Sesion Sobre Guatemala (Madrid, 27 al 31 de Enero de 1983), Coleccion Holandesa, Caja No. 86, Tribunal Permanente de los Pueblos, 1979-1990, CIRMA; House Committee on Foreign Affairs and its Subcommittee on Human Rights and International Organizations, Religious Persecution as a Violation of Human Rights: Hearings and Markup before the Committee on Foreign Affairs and its Subcommittee on Human Rights and International Organizations, 97th Cong., 2nd sess., (Washington, D.C.; U.S. Government Printing Office, 1982): 698-784.
} 
perished or disappeared at the hands of the army. ${ }^{125}$ Military actions against Guatemalan villages turned over a million people into refugees. ${ }^{126}$

Influenced by Ríos Montt's evangelical faith, Reagan asserted that the Guatemalan government had "been getting a bum rap" from the liberal news media. ${ }^{127}$ According to a news correspondent reporting on the meeting in Honduras, "one administration aide said the president was impressed by the intense, forceful style of the Guatemalan as well as Rios Montt's uncompromising faith in God." ${ }^{128}$ Afterwards, Reagan expressed his desire to reinstate military aid to the regime, and over the ensuing months his administration worked assiduously to find ways to provide support to Ríos Montt. ${ }^{129}$ National Security Advisor William P. Clark assured Jorge Serrano Elías, a neo-Pentecostal acolyte Ríos Montt had sent to the United States as his personal emissary, that the Reagan administration was "doing its best" to convince Congress to get them to be more responsive to and positive about Guatemala. ${ }^{130}$

Evangelicals in the United States also pressured Congress and the administration to extend military aid to Guatemala. In the weeks before and after Reagan's meeting with Ríos Montt, letters from supportive evangelicals poured into Washington. ${ }^{131}$ Many emphasized personal connections to Guatemala, referencing missionary work and independent travel there as religious leaders. They often parroted the messages about Ríos Montt that the evangelical press, Christian opinion leaders, and the regime itself put forth. One pastor writing to Reagan noted that

${ }^{125}$ Garrard-Burnett, Terror, 7. Garrard-Burnett notes that this figure is an estimate based on two truth commission reports.

126 Ibid, 6.

${ }^{127}$ Francis and Wallace, "Headline," 5 December 1982.

128 Ibid.

${ }^{129}$ United States, Department of State, "President's Statement Following Meeting with Guatemalan President Rios Montt," November 22, 1982; Ikle to Weinberger, Department of Defense Memo, 20 December 1982.

${ }^{130}$ William P. Clark, "Memorandum of Conversation between William P. Clark and Jorge Serrano," Confidential Memorandum (3 May 1983), DDRS, Document Number: CK3100561878, 3.

${ }^{131}$ Loren Triplett to Ronald Reagan, 15 December 1982, Triplett, Loren (Mildred) ( - 1989), Assemblies of God World Missions Archives, FPHC; Letter, Senator Roger Jepsen to William P. Clark, 17 September 1982, ID \#129022, CO060, WHORM: Subject File, Ronald Reagan Library; Letter, Daniel Crane to Ronald Reagan, 24 September 1982, ID \#100944, CO060, WHORM: Subject File, Ronald Reagan Library. 
he too lamented the "bum rap" he believed Ríos Montt had received in the American press.

Based on his conversations with Guatemalans in the rural highlands, he argued:

I believe his government is very humane, progressive and motivated by great integrity. I do hope you will be able to get the modest aid for Guatemala which has been requested. Their helicopter situation is critical, both for defense and evacuation of villages when the communists strike. ${ }^{132}$

Letters from rank and file evangelicals in the United States to the president, cabinet members, and congressional representatives made manifest the power of the evangelical network to control and propagate its message and political objectives from the elite level to the grassroots.

Ríos Montt and his advisors, cognizant of the influence that this network had on evangelicals in the United States and, potentially, their elected representatives, invited a group of fifteen evangelical leaders to visit Guatemala in late December, 1982. The group included Billy Melvin, executive director of the National Association of Evangelicals, Jerry Ballard, director of World Relief, David Howard, executive director of the World Evangelical Fellowship, J. Philip Hogan, executive director of the Assemblies of God Division of Foreign Missions, and Christopher Moree, a representative from the World Missions Division of the Church of God, among others. Ríos Montt's advisors choreographed the four day trip with great care. On the first morning, the group visited the National Palace for a briefing with the president's cabinet members. J. Philip Hogan reported that Ríos Montt canceled one of his morning meetings in order to pray with them before the session:

Accordingly, he came in in a very humble fashion, began to praise the Lord and give glory to His name and tell about how real Jesus was to him and how he wanted to serve God and his country. Most everyone was completely taken off their feet to find him a bubbling over, hallelujah, praise God, shouting charismatic. There didn't seem to be anything superficial about it. He spoke in glowing terms of his relationship with the

\footnotetext{
${ }^{132}$ Letter, W. S. McBirnie to Ronald Reagan, 17 December 1982, ID \#115961, CO060, WHORM: Subject File, Ronald Reagan Library.
} 
Lord. ${ }^{133}$

Thus primed, the visitors listened attentively to the information they received about the military, political, and refugee situations confronting the Guatemalan government. Next, U.S.

Ambassador Chapin spent over an hour and a half with the group, going "almost overboard in his endorsement of President Ríos and what he is doing in Guatemala." ${ }^{134}$ Chapin spoke about the improved human rights situation, reassuring the evangelical representatives that Ríos Montt had ended all state-directed killings, and suggesting that any soldiers committing acts of violence had just "been a little slow to get the message." ${ }^{135} \mathrm{He}$ also emphasized the extent to which President Reagan supported Ríos Montt. In between meetings with government officials, the visitors conversed with local missionaries and Guatemalan evangelicals, all of whom emphasized their faith in the general and their sense that his "efforts have been blessed of God in helping to restore peace to their troubled country. . . and renewed vigor to the Evangelical community in Guatemala." ${ }^{136}$

The next day, the group boarded military helicopters and flew ninety miles north of the capital to visit a refugee camp in a region occupied by the insurgency. ${ }^{137}$ Hogan described the camp in terms that revealed the ideological lens through which both he and his hosts understood Ríos Montt's rural pacification program. Declaring the conditions better than those he had observed in Southeast Asia and North Africa, Hogan stated that the camp contained "about 6,000 to 10,000 refugees who have, because of the scorched-earth policy of the communists, had to flee their little farms and villages for protection." 138 Once the government overcame the insurgency,

\footnotetext{
${ }^{133}$ J. Philip Hogan to John Bueno and Loren Triplett, Memorandum, 7 January 1983, "Guatemala (1980-1989)," Assemblies of God World Missions Archives, FPHC.

${ }^{134}$ Ibid.

${ }^{135}$ Ibid.

${ }^{136}$ Christopher Moree, “Missions Editor Visits Guatemala." Evangel 73, no. 3 (11 April 1983): 18.

${ }^{137}$ Hogan, Memorandum, 2.

${ }^{138}$ Ibid.
} 
the villagers could return to their land, he asserted. ${ }^{139}$ Such accounts aimed explicitly to counter claims from human rights organizations and internal dissident groups that Ríos Montt's rural pacification program was a "scorched-earth policy." 140

On the final evening of the trip, Ríos Montt hosted a dinner at the palace for the visitors, where he "shared his Christian testimony and spoke informally about some of his hopes for Guatemala," before asking his guests to "pray for him and his government." ${ }^{141}$ Upon their return to the United States, the participants published laudatory accounts and analyses of their visit in evangelical magazines. Moree urged readers of Evangel, the official Church of God magazine, to take the Guatemalan president "at face value," arguing that his regime had "demonstrated a great respect for human rights" while noting that "recently captured documents indicate that the guerrillas themselves believe they have been set back twenty-five years in their struggle because of the new attitude of this government, its representatives, and the armed forces." ${ }^{142}$ Hogan praised Ríos Montt for fighting the "dangerous and growing insurgency," for establishing a state council that included Mayan representatives, and for speaking to the Guatemalan citizens about "his personal salvation and his aspirations that Guatemala be a peaceful, Christian land." 143 Other periodicals picked up and referenced these accounts, ensuring that they received wide distribution among believers in the United States. ${ }^{144}$

These accounts, in turn, worked their way into letters that trip participants and other

\footnotetext{
139 Ibid.

${ }^{140}$ Council on Hemispheric Affairs, “COHA Report Marks Shameful Reagan-Rios Montt Meeting,” Press Release (December 4, 1982), Colección de Robert Trudeau sobre Política de Guatemala, Serie: Documentos, Documento RHT 833, CIRMA; Francis and Wallace, "Reagan/Guatemala Aid," NBC Evening News; United States Department of State, "Guatemala: Reports of Atrocities Mark Army Gains," August 1982, Secret Report, DNSA; Mark Whitaker and Beth Nissen, "Guatemala: Beans-and-Bullets Politics," Newsweek (13 December 1982): 56.

141 Moree, "Missions," 18.

142 Ibid, 26.

143 J. Philip Hogan, “A visit to 'The New Guatemala,"” Pentecostal Evangel (27 February 1983): 8.

${ }^{144}$ Rowland, "Guatemala," 2-4; "Clevelander visits Guatemala with evangelical team," Cleveland Daily Banner (2 January 1983): 17-18.
} 
evangelicals wrote to encourage their congressional representatives to approve military aid to Guatemala. Writing to Missouri Congressman Gene Taylor, Hogan emphasized the threat that the "communist insurgents" posed to Ríos Montt's government. He referenced his personal conversations with soldiers, refugees, and local pastors who asserted that Ríos Montt had made great strides toward protecting human rights, stating that because this information originated from "the grass roots," he trusted in its veracity completely. ${ }^{145}$ Hoping to provide additional evidence to encourage support for military aid and to counter negative press from human rights organizations, Taylor forwarded Hogan's letter to William Clark, noting, "because of recent newspaper accounts of the situation there, I thought that Mr. Hogan's evaluation would be of interest to you." ${ }^{146}$ Clark agreed, thanking Taylor and disclosing that, "Mr. Hogan's account is very similar to others that we have received." 147

Despite the best efforts of the Reagan administration and the evangelical community, however, congressional opposition to direct military aid to the regime persisted. Although Reagan and his advisors searched for ways to maneuver around Congress and provide military assistance without congressional approval, they failed to do so amid news of extrajudicial killings and the murder of three USAID workers by Guatemalan soldiers. ${ }^{148}$ Offering the needed helicopter parts for cash rather than as a grant emerged as the best option. In early 1983, the Reagan administration announced its approval of Foreign Military Sales funding to Guatemala for purchase of helicopter spare parts in recognition of "progress in human rights achieved by

\footnotetext{
145 J. Philip Hogan to Gene Taylor, 11 January 1983, “Hogan, J. Philip (Virginia) (- 2001),” Assemblies of God World Missions Archives, FPHC.

${ }^{146}$ Gene Taylor to William Clark, 25 January 1983, “Hogan, J. Philip (Virginia) (- 2001),” Assemblies of God World Missions Archives, FPHC.

${ }^{147}$ Letter, William P. Clark to Congressman Gene Taylor, 7 February 1983, folder “[Guatemala] (3)," box 2, Alfonso Sapia-Bosch Files, Ronald Reagan Library.

${ }^{148}$ Frederic Chapin, United States Embassy, Guatemala to United States Department of State, Washington, "Ambassador's Comments on the Information concerning the Deaths of the Three AID Project Related Persons," 15 November 1983, Confidential Cable 009871, DNSA; William Chislett, "Peace Prospects poor in Guatemala," ISLA (23 March 1983): 30, in Civil War, Society and Political Transition in Guatemala, Series 5, Roll 13.
} 
President Ríos Montt since he came to power."149

Citing a lack of money to purchase the needed spare parts, Ríos Montt ignored the offer and looked to the U.S. evangelical network for more substantive support. ${ }^{150}$ Gospel Outreach and other Christian benefactors provided assistance in acquiring military materiel, including the elusive spare helicopter parts, from private dealers in the United States as well as from Canada and Israel. ${ }^{151}$ Love Lift International coordinated and funded many of these purchases. ${ }^{152}$ U.S. evangelicals also lent direct support to the rural pacification program. Gospel Outreach and el Verbo members worked alongside the army in establishing the "model villages" or strategic hamlets in the Guatemalan countryside. ${ }^{153}$ Love Lift International played a key role in this effort, establishing the Fundación Para Ayuda los Pueblos Indígenas to provide funds, personnel, and administrative support to run the villages. ${ }^{154}$ These efforts comported with Ríos Montt's earlier boast to "bring hundreds of American Christians down as volunteers to reconstruct the Quiche, Huehuetenango, San Marcos and other departments as the army begins to

\footnotetext{
${ }^{149}$ George P. Shultz to United States Embassy, Guatemala, "FMS Cash Sales to Guat[e]mala," (January 6, 1983), Confidential Cable 003022, Digital National Security Archive, nsarchive.chadwyck.com (accessed 19 January 2012), 3.

${ }^{150}$ James W. Connally to Alfonso Sapia-Bosch, "Helo Spare Parts for Guatemala," memorandum, folder "Guatemala [2]," Box 2, Alfonso Sapia-Bosch Files, Ronald Reagan Library.

${ }^{151}$ Ibid; William Clark to Alfonso Sapia-Bosch, Memorandum, (31 May 1983), DDRS, Document Number: CK3100561309; "Mercy Helicopters for Rios Montt," CounterSpy (March-May 1983): 47-49, Archivo de la Coordinadora Alemana de Solidaridad con Guatemala, Cartapacio No. 156 Coleccion Infostelle Del 13.01.06 Al 13.01.07, CIRMA; Alfonso Sapia-Bosch and Oliver North to William P. Clark, "Guatemala," Memorandum, 1 August 1983, folder "Guatemala - Jul - Dece 83," "[Guatemala] (3)," Box 2, Alfonso Sapia-Bosch Files, Ronald Reagan Library; Al Sapia-Bosch to Bud McFarlane, cable, 5 August 1983, folder "Guatemala - Jul - Dece 83," "[Guatemala] (3)," Box 2, Alfonso Sapia-Bosch Files, Ronald Reagan Library.

${ }^{152}$ Serrano noted that, with International Love Lift funding, they "had been able to get the helicopter parts they needed from 'a Christian friend in Canada' at 1/10 the cost they would have been charged by the US." Clark, "Memorandum of Conversation," (3 May 1983), 2.

${ }^{153}$ Infoprensa, "Guatemala: La Contrainsurgencia de Rios Montt," Informe (Junio de 1983), manuscript, Coleccion Holandesa, Revistas/Investigaciones Documentos no seleccionados etc. 1983-1988, Caja No. 85, CIRMA; Iglesia Guatemalteca en el Exilio, "Reconstruir con permiso del rey," Informe Especial: FUNDAPI (June 1983), Coleccion Holandesa, I.G.E. Signatura 31, Document 55, CIRMA; Stoll, "Evangelicals, Guerrillas, and the Army," 109; Melander, Hour of God, 225.

${ }^{154}$ Ibid.
} 
pacify them." 155 Assuming churches would raise funds for this effort, some State Department officials found the strategy promising enough to promote it to others within the U.S. government. ${ }^{156}$

By Rios Montt's own description, the planned model villages blended military strategy he learned at the School of the Americas with the "communitarian" Christian values of the Gospel Outreach church. ${ }^{157}$ Although newspaper reports detailed the dismal conditions, as well as the compulsory conscription of male refugees into civilian armies to fight the guerrillas, U.S. evangelicals claimed the model villages provided Christian charity, spiritual uplift, and a bulwark against communism. ${ }^{158}$ As one press release noted, "food, shelter, clothing, and medicine are being provided to those in need; along with Army protection, training of civil patrol groups, and weapons to defend themselves." 159

Ultimately, U.S. evangelical oversight of the model villages outlasted Ríos Montt's tenure in office. Gospel Outreach and Love Lift International continued their ministrations - with USAID funds - even after Óscar Humberto Mejía Victores removed Ríos Montt in the August, 1983 coup. ${ }^{160}$ The network linking U.S. and Guatemalan evangelicals proved resilient. Although evangelicals enjoyed a period of particular power and visibility during Ríos Montt's presidency, their involvement within and influence on Guatemalan society and politics persisted long after he stepped down.

\section{Ousting "Dios” Montt}

${ }^{155}$ Chapin, "Piedra/Carbaugh Visit," (May 19, 1982), 3.

${ }^{156}$ Richard B. Stone to Thomas Enders, "Repatriation of Guatemalan Refugees," memorandum, 10 March 1983, folder "[Guatemala] (3)," Box 2, Alfonso Sapia-Bosch Files, Ronald Reagan Library.

${ }^{157}$ Raymond Bonner, "Guatemala Leader Reports Aid Plan," New York Times (20 May 1982): A6.

${ }^{158}$ John Rose, "Despite Rios Montt's Overthrow: Eureka church to continue Guatemalan strategic hamlet aid," The San Francisco Bay Guardian (17 August 1983): 17.

${ }^{159}$ Guatemala Task Force, "Guatemala Situation Fact Sheet," Guatemala in The North American Congress on Latin America (NACLA) Archive on Latin Americana, roll 19, file 90, frame 899.

${ }^{160}$ Ibid; "Disputed Guatemala villages get U.S. funds," San Francisco Examiner (13 December 1984): A22. 
The evangelicalism that helped Ríos Montt gain and hold power in Guatemala in 1982 contributed to the unraveling of his presidency in 1983. Although coup rumours had plagued his government since he had declared himself president, they became quite real by June $1983 .{ }^{161}$ Disgruntled members of the military and major political parties, including original junta member Gordillo Martínez and a former MLN vice president, complained on television about Ríos Montt's "religious fanaticism" and "use of the presidency as a pulpit to promote his evangelical beliefs." 162 Brigadier General Echeverría asked Ríos Montt to restore constitutional government and stop mixing religion with politics. ${ }^{163}$ Army leaders expressed frustration about the power evangelical advisors Bianchi and Contreras exercised within the government. ${ }^{164}$ Despite the simmering unrest, Ríos Montt refused to let his advisors resign. ${ }^{165}$

The State and Defense Departments expressed concern about the coup rumblings, reiterating their approval of Ríos Montt's counterinsurgency program, progress on human rights, and political moderation. ${ }^{166}$ Defense Department experts estimated that the general could stay in power only with army backing; without this support, a coup was imminent. ${ }^{167}$ On August 8 , 1983, disgruntled senior army commanders overthrew Ríos Montt and placed Mejía in power,

\footnotetext{
${ }^{161}$ Frederic Chapin, United States Embassy, Guatemala to United States Department of State, Washington, "Coup Rumors," 24 March 1983, folder "Guatemala, Vol. I, 1/20/81 - 7/31/84 [2 of 5]," Box 52, NSC Executive Secretariat: Country File, Latin America, Ronald Reagan Library; Memorandum, Alfonso Sapia-Bosch to William P. Clark, "Guatemala," 14 July 1983, folder "Guatemala, Vol. I, 1/20/81 - 7/31/84 [5 of 5]," Box 52, NSC Executive Secretariat: Country File, Latin America, Ronald Reagan Library.

${ }^{162}$ Paul D. Taylor, United States Embassy, Guatemala to United States Department of State, Washington, "Disturbances of June 29: Sitrep 4," 29 June 1983, Secret Cable 005231, DNSA.

${ }^{163}$ Defense Intelligence Agency, "BG Rios Montt, Vulnerable and under Attack," 14 June 1983, Confidential Cable, DNSA. of Government-A Week and a Half after the Crisis Broke into the Open," 8 July 1983, Confidential Cable 005514, DNSA.

${ }^{166}$ Director of Intelligence, "Guatemala: Prospects for Political Moderation: An Intelligence Assessment," (August 1983): v, folder "Guatemala - Oliver L. North, NSC Staff (3 of 3)," Box 12, Oliver North Files, Ronald Reagan Library. ${ }^{167}$ Ibid.
} 
stating "that they acted to rid the country of a religious fanatic who has ignored the separation between church and state." 168

Defense Department officials had worried that if the army or a right wing political faction ousted Ríos Montt, the new regime would be as oppressive, corrupt, and abusive as the one he had replaced in 1982. ${ }^{169}$ The State Department expected that, "if he is overthrown, it is likely he will be replaced by a reactionary government whose repressive actions will play into the hands of the Marxist guerrillas." ${ }^{170}$ These concerns proved prescient. Soon after Mejía took power, reports of human rights abuses multiplied. The army returned openly to the practices of the Lucas regime, utilizing military death squads and political repression to control the countryside. $^{171}$

After the coup, Ríos Montt went into retreat for several weeks with his church elders, then retired to private life, devoting his time to working at el Verbo. ${ }^{172}$ Nonetheless, he retained an interest in returning to politics. In 1989, he founded a new political party, then served multiple terms in Guatemala's Congress and made several attempts to run for president.

Ríos Montt nurtured his contacts with evangelicals in the United States during his years in and out of office. He attended the National Prayer Breakfast in Washington in 1985, and maintained a correspondence with Douglas Coe of the Fellowship Foundation. ${ }^{173}$ He traveled

\footnotetext{
${ }^{168}$ Hugh Montgomery to George P. Schultz, "Coup in Guatemala Deposes Rios Montt,” 8 August 1983, Secret Information Memorandum, DNSA, 1.

${ }^{169}$ Director of Intelligence, President, 5.

${ }^{170}$ Memorandum, Charles Hill to William P. Clark, "Working Visits for Foreign Leaders: July-December 1983," 11 April 1983, folder "[Guatemala]: Rios Montt Working Visit (Guatemala)," Alfonso Sapia-Bosch files, Ronald Reagan Library.

${ }^{171}$ Robert C. Mcfarlane to Ronald Reagan, "Memorandum from Secretary of State Shultz Concerning our Relations with Guatemala," (8 December 1983), document number CK3100554630, DDRS; Department of State Bureau of Intelligence and Research, "Guatemala: Death Squads Resume Activity," 21 November 1983, Confidential Analysis, DNSA.

172 “Efraín Ríos Montt," Pentecostal Evangel (27 November 1983), Guatemala (1980-1989), Assemblies of God World Missions Archives, FPHC.

${ }^{173}$ Douglas Coe to General Ríos Montt, May 16, 1985, Records of the Fellowship Foundation, 1937-1988 Collection 459, Box 223, Folder 43 “Guatemala 1985," and Ríos Montt to Douglas Coe, December 5, 1986, Records
} 
within the United States to raise funds for Love Lift International, speaking at evangelical churches throughout the country. ${ }^{174}$ For these audiences, he emphasized the ongoing threat that communism posed to Central America, and reiterated his belief that he had made critical improvements for the people of Guatemala during his time in power. Indeed, he insisted throughout his 2013 trial for genocide and crimes against humanity that he had not ordered military violence against the Maya in 1982-1983. The staggering evidence the prosecution presented at the trial belies these assertions. ${ }^{175}$

The support that Ríos Montt garnered from evangelical Christians in the United States illuminates a great deal about the religious and ideological beliefs that grounded evangelical understandings of human rights and anti-communism. American evangelicals who visited Ríos Montt, el Verbo, and their brethren in Guatemala believed these individuals when they asserted that the guerrillas, not the army, committed the majority of the violence against the Guatemalan people. They trusted Ríos Montt when he argued that pacifying the countryside and removing the communist threat would bring justice, peace, and human dignity to poor villagers. These messages resonated with pre-existing evangelical beliefs about communism as an existential threat not only to a nation, but to religious faith as well. When Guatemalan evangelicals claimed that under Ríos Montt, they could proselytize without fear of retaliation from the guerrillas, it reinforced deeply held hopes that evangelicals might achieve the Great Commission during their

of the Fellowship Foundation, 1937-1988 - Collection 459, Box 223, Folder 44, “Guatemala 1986-1987," Billy Graham Center, Wheaton, IL.

${ }^{174}$ Dean G. Peerman, "What ever happened to Ríos Montt?" Christian Century 102 no 28 (September 25 1985): 819-820.

${ }^{175}$ Although the Guatemalan court convicted Ríos Montt of genocide and crimes against humanity on May 10, 2013, the Constitutional Court of Guatemala vacated the conviction on technical grounds. For excellent coverage of the trial and the tremendous amount of evidence that the prosecutors presented to support the allegations of genocide and crimes against humanity, see The Open Society Justice Initiative, "The Trial of Efrain Rios Montt \& Mauricio Rodriguez Sanchez," accessed 22 September 2013, http://www.riosmontt-trial.org. 
lifetimes. ${ }^{176} \mathrm{Had}$ U.S. evangelicals consulted the Mayan and Catholic refugees who fled across the border into Mexico to escape army violence, they might have heard a different, more realistic perspective on the situation. Instead, they and the Reagan administration backed Ríos Montt, aiding and abetting genocidal state violence in the process.

Evangelicals believed religious liberty—-the freedom to evangelize—was the core human right, because they saw salvation as the basis for human freedom and the truest cure for man's suffering. When Ríos Montt adopted the distinctive language and leadership style of their particular form of apocalyptic American Christianity, U.S. evangelicals thought they had found in the Central American leader the personification of their most deeply cherished objectives. Support for such a "Brother in Christ" flowed freely in response.

${ }^{176}$ Moree, "Missions," 17-18. 